Uniwersytet Gdański

karolinaczemplik@gmail.com

\title{
WYBRANE NAZWISKA MIESZKAŃCÓW PARAFII OSIE NA PODSTAWIE KSIĘGI CHRZTU Z LAT 1751-1760
}

Słow a tematyczne: onomastyka, antroponimia, nazwiska polskie

Osie to wieś gminna położona w województwie kujawsko-pomorskim, w powiecie świeckim, we wschodniej części Borów Tucholskich. Wzmożone osadnictwo na terenie dzisiejszej gminy nastapiło w XIII w. i związane było z intensywną akcją kolonizacyjną na terenie północnej części kasztelanii świeckiej. Osadnictwo początkowo przebiegało na tzw. prawie polskim (powstanie Miedzna), później zaś na prawie niemieckim (utworzenie Osia, Brzezin, Wierzchowa, Łążka oraz młyna w Tleniu). W kolejnych wiekach powstał Jaszcz (XV w.), Młyn w Żurze (XVI w.), a w XVII w. - Oski Piec i Grzybek. Zakładanie kolejnych wsi na omawianym obszarze spowodowane było intensywną eksploatacją zasobów przyrody, z którą wiązała się budowa m.in. młynów, tartaków, a także smolarń. Ostatnia faza osadnictwa na terenie gminy związana była $\mathrm{z}$ akcją kolonizacyjną prowadzoną w końcowym okresie istnienia Rzeczypospolitej Polskiej. W jej rezultacie powstały: Pruskie, Stara Rzeka, Sobiny oraz Gzelowe' ${ }^{1}$. Warto również zaznaczyć, że teren gminy wielokrotnie ucierpiał w wyniku licznych zmagań z Krzyżakami, najazdu wojsk szwedzkich, a także działań wojennych toczonych w XVIII w. (wojna północna (1700-1721), wojna o tron polski (1733-1735) oraz wojna siedmioletnia (1757-1763)).

Tematem niniejszego artykułu jest analiza nazwisk mieszkańców parafii Osie $\mathrm{z}$ lat 1751-1760. Zdecydowano się na taką cezurę, ponieważ w tym przedziale czasowym zarejestrowana została zbliżona liczba ochrzczonych osób ${ }^{2}$ na terenie parafii, obejmującej notowane w tym okresie wsie ${ }^{3}$ : Brzeziny, Miedzno, Osie, Pruskie,

\footnotetext{
${ }^{1}$ http://www.osie.pl/historia/historia.html (dostęp 28 VIII 2015).

21751 r. — 44 mieszkańców, 1752 r. — 36 mieszkańców, 1753 r. — 39 mieszkańców, 1754 r. — 18 mieszkańców, 1755 r. - 41 mieszkańców, 1756 r. — 45 mieszkańców, 1757 r. — 27 mieszkańców, 1758 r. - 25 mieszkańców, 1759 r. — 28 mieszkańców, 1760 r. — 42 mieszkańców.

${ }^{3}$ W połowie XVIII w. do parafii Osie należały również następujące wsie: Grzybek, Gzelowe, Jaszcz, Łążka, Oski Piec, Sobiny, a także młyn w Tleniu (por. http://www.osie.pl/historia/historia.html; dostęp 28 VIII 2015).
} 
Stara Rzeka i Żur ${ }^{4}$. Analizowany materiał onimiczny stanowi jedynie wycinek pracy autorki, która przygotowuje dysertację doktorską poświęconą antroponimii parafii Osie .

Badany materiał został wyekscerpowany z księgi metrykalnej obejmującej lata 1741-1788. Do dzisiejszych czasów dokument ten zachował się w bardzo dobrym stanie, a wpisy, mimo odręcznego sposobu rejestracji, są dość czytelne. Poddane analizie archiwalia znajdują się obecnie w Archiwum Diecezjalnym w Pelplinie. Analizowane nazwiska pochodzą z 33 kart księgi chrztu, pisanej po łacinie w sposób ciągły ${ }^{6}$. W każdym rejestrze zostały zawarte następujące informacje: imię dziecka, imiona i nazwiska rodziców naturalnych oraz rodziców chrzestnych, data chrztu (zazwyczaj również data urodzenia), a także nazwa wsi, z której pochodzi ochrzczone dziecko. Stronice księgi metrykalnej są numerowane, numery stron zostały jednak wpisane wtórnie, najprawdopodobniej przez pracownika archiwum, a nie przez sporządzającego metryki. Potwierdzeniem tego przypuszczenia może być m.in. to, że na wszystkich kartach numery naniesione zostały tym samym kolorem atramentu i tym samym charakterem pisma, który nie odpowiada charakterowi pisma żadnej z osób rejestrujących chrzty.

W pracy używa się terminu nazwisko z założeniem, że w odniesieniu do nazw osobowych z badanego przedziału czasowego jest to pewne uproszczenie (por. Kaleta 1991; Rymut 2003). Ten rodzaj antroponimu nie podlegał ścisłej ochronie prawnej aż do początku XIX w., gdyż jego forma językowa nie miała jeszcze ustabilizowanej postaci ${ }^{7}$ (Grzybowski 1957; Rymut 1998). Współczesne znaczenie wyrazu nazwisko ukształtowało się dopiero w XX w. (Rymut 1999: XV). W wyekscerpowanym materiale za tego typu onimy uznano oficjalne nazwy osobowe występujące obok imienia, powstałe $\mathrm{w}$ celu dokładniejszej identyfikacji osoby, potencjalnie pozbawione nacechowania emocjonalnego, a także podlegające procesowi dziedziczenia.

Antroponimy zawarte w niniejszym artykule podzielono - za I. Matusiak-Kempa (Kemp 25-26) - na grupy semantyczne, tj. motywowane przez apelatywy, imiona i nazwy miejscowe ${ }^{8}$. Podział w obrębie wymienionych klas semantycznych ilustruje udział polskiego oraz niemieckiego substratu w antroponimii omawianego terenu. Celem zaś analizy i klasyfikacji nazwisk polskich oraz niemieckich jest próba opisu aktu nominacji, a także towarzyszących mu kontekstów pragmatycznych,

${ }^{4} \mathrm{~W}$ analizowanej księdze metrykalnej przeważnie można spotkać nazwę Młyn Żur.

${ }^{5}$ Rozprawa doktorska będzie poświęcona analizie i opisowi nazwisk mieszkańców parafii Osie na podstawie materiału wyekscerpowanego z ksiag metrykalnych z lat 1742-1922.

${ }^{6}$ Karty nr 37-70.

${ }^{7}$ Pierwsze nazwiska w dzisiejszym rozumieniu pojawiły się u szlachty (XV-XVI w.), później natomiast u ludności wiejskiej (XVIII-XIX w.).

${ }^{8}$ Obok wymienionych trzech zasadniczych grup nazwisk, tj. motywowanych przez przezwiska pochodzenia apelatywnego, przez imiona i przez nazwy miejscowe, badaczka opisała również onimy motywowane przez nazwy etniczne. W niniejszym artykule nie uwzględniono tej grupy, ponieważ w wyekscerpowanym materiale źródłowym nie pojawiły się tego typu nazwiska. 
takich jak: widzenie świata, człowieka czy generalizowanie zjawisk w otaczającej rzeczywistości oraz ujmowania tych obserwacji w nazwach.

Pierwszą grupę utworzyły nazwy osobowe derywowane od apelatywów. Za nazwiska formalnie równe wyrazom pospolitym uważa się takie, które mają opozycyjne odpowiedniki apelatywne proste i derywowane, notowane w słownikach. Przezwiska, które stanowiły stadium pośrednie między apelatywem a nazwiskiem, wiązały się najczęściej z takimi cechami człowieka, jak: usposobienie, wygląd, wykonywane zajęcie czy miejsce zamieszkania.

Wśród nazwisk formalnie równych wyrazom pospolitym znalazły się takie nomina propria, które zarówno wskazywały cechy wyróżniające człowieka ze zbiorowości, jak i dostarczały informacji zgodnych z rzeczywistością pozajęzykową, dzięki czemu identyfikowały jednostkę, a zatem pełniły funkcję predykatywną oraz referencjalną. Wśród onimów utworzonych od nazw wykonywanego zajęcia (Kemp 46) znalazło się nazwisko polskie: Valenty Popielarz ${ }^{9}$, rodzice Jan i Marianna, 1751, 39 (n. os. Popielarz < ap. popielarz 'robotnik, który przebierał popiół drzewny'; w XVI-XVIII w. popiół drzewny był również towarem eksportowym służącym do wyrobu ługu, popielarzami nazywani byli zatem ludzie, ' którzy popiół palili, zbierali lub sprzedawali' (NP III 287-288; Ry II 279), a także antroponimy wywodzące się z języka niemieckiego: Christian Hoffmann, rodzice Jacobus i Marianna, 1754, 49 (: niem. n. os. Hoffmann < niem. ap. hofmann 'dworzanin; chłop zobowiązany do pracy na dworze' lub śrwniem. ap. hoveman 'chłop zobowiązany do pracy na dworze; służący na dworze księcia’ Brech I 728; Gott 255, Gór 85; Kemp 191-192; Lic 96-97; NP I 350; Ry I 309; SEMot 5 106; SSNO II 306; Zoder I 758-759); Constantia Meger ${ }^{10}$, rodzice: Andreas i Marianna, 1753, 47 (: niem. n. os. Meeger $<$ niem. ap. meger 'chudy' lub od niem. n. os. Maier//Meier < śrdniem. ap. meier 'zarządca', śrwniem. ap. meier 'ts.' Brech II 228; Gott 418; Heintze 336; Kemp 245; Lic 142; Lex 132; NP I 38; Ry II 82; Zoder II 111) i Elisabeth Schultz, rodzice: Martinus i Elisabeth, 1757, 61 (: niem. n. os. Schult $(z)<$ niem. ap. schulze ‘wójt, sołtys' Brech II 570; Gott 528; Gór 221; Kr: 235; Kemp 284; Lic 196; NP III 364-367; Ry II 558). W grupie antroponimów formalnie tożsamych z wyrazami pospolitymi występują również nazwiska utworzone metaforycznie, użyte w celu identyfikowania człowieka przez zastosowaną metaforę lub metonimię, nie mogły zatem pełnić funkcji predykatywnej, wskazywały tylko na jakąś cechę wspólną człowieka i derywatu oznaczanego przez dany apelatyw (Kemp 46-47); potwierdzają one, że ludzkiemu myśleniu bliższe są ujęcia przenośne niż dosłowne (tamże: 49). Stanowią je nazwiska formalnie równe nazwom istot żywych, np.: Georgina Bocian, rodzice Cristiani i Dorothea, 1752, 43 (n. os. Bocian < ap. bocian 'n. ptaka'

9 Przy każdym nazwisku podaję imiona rodziców naturalnych, rok, w którym dziecko zostało ochrzczone, a także numer karty księgi metrykalnej, na której znajduje się wpis.

${ }^{10}$ Możliwa jest również inna motywacja: od niem n. os. Meger, ta od niem. hipokorystyku Meger, por. im. złożone na Mag-, np. Magher Gott 336; Kemp 245; Ry II 82. 
NP I 194; NP III 45-46; Ry I 43; SSNO I 179); Catharina Lis ${ }^{11}$, rodzice Matheus i Marianna, 1753, 45 (: n. os. Lis < ap. lis 'drapieżnik z rodziny psowatych' Gór 246; Kemp 238; Kr 140; NP III 105-107; Ry II 22; SEMot 1: 145; SSNO III 267); Agneta Mucha, rodzice Albert i Marianna, 1756, 55 (n. os. Mucha < ap. mucha NP I 289-290; Ry II 124; SEMot 3: 173). Tego typu nomina propria mogły pierwotnie wskazywać na takie cechy, jak: szczęście lub płodność (Bocian), chytrość oraz przebiegłość (Lis), czy też, jak w przypadku nazwy osobowej Mucha, np. na człowieka gniewliwego (ma muchy w nosie ${ }^{12}$. Na uwagę zasługują również nazwiska utworzone od: nazw roślin — Marianna Holc ${ }^{13}$, rodzice Jan i Anna, 1752, 43 (niem. n. os. Holc < gniem. ap. holz 'drzewo' Kemp 193; Lex 92; NP I 72; NP II 471; SEMot 5 107; spolonizowane fonetycznie); Anna Kąkol, rodzice Jan i Marianna, 1760, 69 (n. os. Kakol < ap. kakol 'gatunek chwastu zbożowego' NP I 194-195; Ry I 389; SEMot 1 104; SSNO II 561); zjawiska przyrodniczego — Sofia Mróz, rodzice Valentinus i Elisabeth, 1760, 69 (n. os. Mróz < ap. mróz, mrozić Ry II 122 -123; SEMot 1: 172) oraz nazwy miejsca zamieszkania - Jan Zaremba ${ }^{14}$, rodzice Adalbertus i Elisabeth, 1751, 40 (n. os. Zaręba < stp. ap. zaręba, zarąb 'miejsce po wyciętych zaroślach', zarabać 'wyrąbać; zabić bronią sieczną' NP I 439-440; Ry II 726; SEMot 1: 361; SSNO V 269-270). Ponadto wyróżniono antroponim utworzony od nazwy osobowej wskazującej pierwotnie na charakter jej nosiciela: Marianna Smet, rodzice Jacobus i Marianna, 1758, 62 (n. os. Smet < stp. ap. smęt 'smutek', smęcić się 'smucić się', później smutek, smutny NP II 423, 424; Ry II 451; SEMot 1: 279; SSNO V 126). Onimy te być może powstały zgodnie z realizowanym wówczas schematem myślenia, polegającym na porównywaniu jakiejś cechy wyglądu człowieka z wyglądem desygnatu nazywanego przez apelatyw. Możliwa jest również kreacja metonimiczna, która wskazywałaby na sprzedawcę roślin, wytwórcę przedmiotów lub miejsce zamieszkania.

Wśród form derywowanych od nazw pospolitych znalazły się m.in. antroponimy utworzone za pomocą wariantów sufiksu $-s k i^{15}$ : Valentinus Jagielski, rodzice Lucas i Marianna, 1756, 54 (: n. os. Jagiela < ap. jagła, stp. ap. jagty 'kasza z prosa', dawniej też 'proso' Gór 87; Ry I 327), Adalbertus Nowicki, rodzice Michael i Agnete, 1751, 41 (: n. os. Nowy < ap. nowy Gór 159; Ry II 164; SSNO IV 79); Catharina Pierzewski, rodzice Lucas i Regina, 1760, 68 (: n. os. Pierz < ap. pierz 'pióra' Ry II 234), Fabian Skurczewski, rodzice Casimirus i Gertruda, 1758, 62 (: n. os. Skurcz<

11 Możliwa jest również inna motywacja: od n. os. Lis < n. m. Lis, por. n. kilku wsi w pow. kaliskim, łukowskim, poznańskim, brodnickim, lublinieckim SG V 297-298.

12 http://doroszewski.pwn.pl/haslo/mucha (dostęp 15 IX 2016).

13 Możliwa jest również inna motywacja: od dniem. n. os. Holl < ap. holt, holl ‘las' jako przezwisko 'ktoś mieszkający w lesie lub w jego pobliżu', por. n. m. Holz, np. w Bawarii, Westfalii, Wirtembergii, lub n. m. Holtz, Holtzen Gott: 257, też gw. ap. holc 'młody chłopak' Rosp 2 146; SSNO II 307.

14 Możliwa jest również inna motywacja: od n. os. Zaremba $<$ n. herbu Zaremba Gór 248.

15 Derywaty z sufiksem -ski są wielofunkcyjne, tworzą nazwiska odmiejscowe, odapelatywne, patronimiczne oraz służą wyrażeniu funkcji strukturalnej (Skowronek 2001: 154-155). 
ap. skurczyć, skurcz 'skurczenie, ściagnnięcie się mięśni' Ry II 41). Następnie dwa onimy z podstawowym - $k$ - w części sufiksalnej: Matheus Kruczek ${ }^{16}$, rodzice Martinus i Marianna, 1751, 39 (: n. os. Krucz < ap. kruk 'n. ptaka' Gór 121; Ry I 489; SEMot 1: 129; SSNO III 151), Andreas Zimiak ${ }^{17}$, rodzice Jacobus i Marianna, 1753, 47 (: n. os. Zimny < ap. zimny nie tylko 'ciepła niemający', ale także 'ostygły, obojętny, nieochoczy' SL VI 1063, por. zimny na cudze sprawy, zimne serce NP III 424-425); dalej — po jednym z podstawowym -cz- w części sufiksalnej: Josephus Durnowicz $^{18}$, rodzice Martinus i Dorothea, 1753, 44 (: n. os. Durny < ap. durny 'głupi' Ry I 159), a także z podstawowym -ch- w części sufiksalnej: Adam Jarych, rodzice Gregorius i Catharina, 1760, 66 (: n. os. Jary < ap. jary 'wiosenny, młody; silny' Ry I 336) oraz z podstawowym -w- w części sufiksalnej: Simona Olszowy ${ }^{19}$, rodzice Bartholomeus i Marianna, 1752, 44 (n. os. Olsza < ap. olsza, olcha 'drzewo liściaste' NP III 67-68; Ry II 180; SEMot 1: 196). W analizowanym materiale onimicznym wystąpiły również nazwiska derywowane paradygmatycznie za pomocą formantu -a: Apolonia Kądziela, rodzice Matheus i Hedvigis, 1752, 43 (: n. os. Kaqdziel < ap. kadziel 'przędziwo, len, konopie, przyrząd do przędzenia' Ry I 389); Ewa Kruza, rodzice Michael i Catharina, 1760, 65 (: niem. n. os. Kraus(e) lub Krus $(e)<$ śrdniem. ap. krûs 'dzbanek, kufel' lub śrwniem. ap. krūse 'ts.', śrwniem. ap. krûs 'kędzierzawy, lokowaty' Brech II 107; Gott 388; Heintze 307; Kr 130; Lbn II 579; Lex 117; Lic 129; Naum 180; NP I 229-331; NP II 256; Ry I 470-471; Zoder I 994); Marianna Pultyna, rodzice Peter i Hedvigis, 1759, 64 (: n. os. Pultyn < ap. pultyn 'thusty dzieciak' Ry II 321).

Drugą grupę tworzą nazwiska powstałe od imion. Prawdopodobnie wpływ na ich powstanie miało zjawisko identyfikowania jednostki dwoma imionami, z których jedno zaczęło później pełnić rolę nazwiska. Źródłem motywacyjnym dla nazwisk były najczęściej imiona pochodzenia biblijnego, imiona germańskie i słowiańskie.

Wśród analizowanego materiału występują nazwiska utworzone w wyniku transonimizacji imion pełnych, są to: Anna Abraham, rodzice Peter i Anna, 1760, 68 (: n. os. Abraham < bibl. im. Abraham i Abram; Abraham 'ojciec licznego narodu'< akad. im. Aba-am-ra-am 'kochaj ojca'; Abram 'ojciec jest wywyższony' < hebr. ap. $a b$ 'ojciec, tatuś' Gór 15; NP I 31-32; Ry I 1; SEMot 1: 1; SSNO I 4); Josephus Arend, rodzice Laurentius i Magdalena, 1757, 61 (: niem. n. os. Arendt $<$ (w wyniku wydłużenia i kontrakcji) im. Arnold Gór 17; Kemp 125; Kr 17; Lic 43; NP I 33; Ry I 10; Zoder I 153); Symon Lucas, rodzice Paulus i Marianna, 1754, 61 (: n. os. Lucas < łac. im. Lucas Ry II 44; SEMot 2: 81; SSNO III: 342); Christian Samuel, rodzice Christiani i Barbara, 1760, 68 (: n. os. Samuel $<$ im. Samuel $<$ hebr. im. ك̌emū'ĕl 'Bóg wysłuchał' Kr 219; Ry II 395; SEMot 2: 118; SSNO V 11). Z kolei jednostki

\footnotetext{
${ }^{16}$ Sufiks -ek pełni głównie funkcję deminutywno-ekspresywną (tamże: 141-142).

17 Sufiks -ak pełni głównie funkcję deminutywną i patronimiczną (tamże: 140-141).

${ }_{18}$ Sufiks -owicz pełni głównie funkcję patronimiczną (tamże: 136-137).

19 Sufiks -owy występuje jako formant przymiotnikowy (tamże: 161).
} 
odimienne formalnie równe imionom skróconym lub pierwiastkom hipokorystycznym, powstałym poprzez dezintegrację części imienia pełnego, to: Mathias Barcz, rodzice Mathias i Anna, 1759, 65 (: n. os. Barcz < im. Barttomiej < aram. im. BarTholomaj 'syn oracza' Lic 46; NP I 40-41; NP II 310; Ry I 20; SEMot 2: 19; SSNO I 94); Filip Tys, rodzice Mathias i Marianna, 1751, 40 (: n. os. Tys < im. na Ty-, typu Tymoteusz Ry II 635). Onimy odimienne utworzone za pomocą sufiksów to nazwiska z formantem -ewicz//-owicz o charakterze patronimicznym (Skowronek 2001: 136-137): Mariann Julewicz, rodzice Michael i Catharina, 1751, 40 (: n. os. Jul < im. Julian lub Juliusz, z łac. im. Iulianus, Iulius Ry I 359); Jan Zdanowicz, rodzice Jacobus i Constantia, 1752, 42 (: n. os. Zdan < od im. złożonych typu Zdamir Ry II 733), a także liczne antroponimy z podstawowym - $k$ - w części sufiksalnej o charakterze deminutywno-ekspresywnym (Skowronek 2001: 141-143): Adalbertus Gacek, rodzice Michael i Anna, 1757, 61 (: n. os. Gac ${ }^{20}<$ im. Gawet Gór 66; NP I 142-143; Ry I 211); Catharina Radka, rodzice Jan i Marianna, 1757, 60 (: n. os. Rad < im. złożonych typu Radosław, Radomir Kr 201-202; NP I 68; Ry II 330-331), Ewa Reszka, rodzice David i Elisabeth, 1759, 63 (n. os. Resz < im. Radostaw; hipokorystyki Radek i Reszek ulegały jako nazwiska różnym przekształceniom: polski proces przejścia $r a-<r e-$, zniemczenie przyrostka -ek jako dniem. -ke, wtórna polonizacja przez wymianę końcowego -e > - $a$ Kr 207-208; NP I 348-349; Ry I 340; SSNO IV 462); Lucas Stasik, rodzice Franciscus i Eva, 1752, 44 (: n. os. Stas < im. na Sta-, typu Stanistaw Ry II 478).

Kolejną grupę stanowią nazwiska derywowane od nazw miejscowości. Są one przede wszystkim związane ze sposobem identyfikacji osoby polegającym na wskazaniu jej miejsca pochodzenia, zamieszkania lub posiadania przez nią dóbr ziemskich, czyli wyrażeniu relacji przestrzennych albo własnościowych. Występowanie określeń odmiejscowych, oprócz stosunkowo przejrzystego sposobu tworzenia onimów, związane było również z nacechowaniem socjologicznym, ponieważ takie formy uważano za nazwiska szlacheckie, a więc elitarne i nobilitujące, w przeciwieństwie do nazwisk odapelatywnych oraz odimiennych, postrzeganych jako charakterystyczne dla mieszczan i chłopów. Ponadto nazwiska odmiejscowe mogły wcześniej służyć do opisu jednostek zmieniających miejsce pobytu lub wskazywać na nowych przybyszów w danej okolicy. W analizowanym materiale onimicznym wystapiło nazwisko derywowane za pomocą końcówki fleksyjnej $-i$ : Petrus Czerwiński, rodzice Ignatius i Sophia, 1758, 63 (: n. m. Czerwińsk w pow. starogardzkim Gór 47-48; Kemp 152; NP II 225; Ry II 114; SG I 836-839), a także liczne antroponimy derywowane za pomocą formantu -ski//-cki (por. Skowronek 2001: 142-143): Catharina Białachowski, rodzice Jan i Marianna, 1751, 41 (: n. m. Białachowo w pow. starogardzkim Gór 25; Ry I 32; SG I 180); Catharina Brodawski, rodzice Mathias i Catharina, 1756, 57 (: n. m. Brodowo w pow. średzkim lub w pow.

${ }^{20}$ Przyrostek -c tworzył takie zdrobnienia, jak: Kac od Kazimierz, Pac od Pawet, Mac od Maciej (NP I 142-143). 
działdowskim Ry I 53; SG I 370, SG XV/1 233); Stephanus Chmielewski, rodzice Albert i Brigida, 1751, 31 (: n. m. Chmielewo w pow. bydgoskim Gór 41; Kemp 147; Kr 57; Ry I 78; SEMot 3: 22; SG I 587-588; SSNO I 319); Catharina Krzyżowski, rodzice Stanislaus i Sophia, 1757, 59 (: n. m. Krzyżewo w pow. braniewskim lub ełckim Ry I 481; SG IV 818-821); Matheus Kukliński, rodzice Josephus i Elisabeth, 1756, 57 (: n. m. Kuklinów w pow. krotoszyńskim Gór 125; Kemp 228; Kr 133-134; Ry I 487; SEMot 3: 94; SG IV 884-885; SSNO III 190); Constantia Prabucki, rodzice Mathias i Theressa, 1755, 52 (: n. m. Prabuty w pow. kwidzyńskim Gór 180; Kr 196; Ry II 292; SG IX 9); Ageta Racławski, rodzice Jacobus i Agniesia, 1751, 40 (: n. m. Racławice w pow. ostrzeszowskim Ry II 330; SG IX 366-368; XV/2 532; SSNO IV 414); Marianna Rogalski ${ }^{21}$, rodzice Jan i Marianna, 1751, 40 (: n. m. Rogalin w pow. sępoleńskim lub w pow. radziejowskim Gór 190; Ry II 355; SG IX 658-660); Antonius Smoleński, rodzice Casimirus i Anna, 1760, 68 (: n. m. Smoleń w pow. olsztyńskim lub Smolno w pow. puckim albo w pow. toruńskim Gór 205; Ry II 452; SEMot 3: 180; SSNO V 129); Justyna Sukowski²2, rodzice Josephus i Marianna, 1756, 57 (: n. m. Żukowo w pow. kartuskim zniemczonej na Zuckau lub Suckau NP III 354; Ry II 506; SG XIV 848-850); Laurentius Szopski, rodzice Laurentius i Sophia, 1759, 65 (: n. m. Szopy w pow. elbląskim Ry II 548, SG XII 21, SG XV/2 645); Thomas Żabiński, rodzice Laurentius i Marianna, 1760, 13 (: n. m. Żabno w pow. chojnickim Gór 251; Kr 275-276; NP II 333, III 293, 316; Ry II 755; SEMot 3: 230; SG XIV 717-718; XV/2 723; SSNO VI 348); Thomas Żukowski, rodzice Michael i Catharina, 1751, 42 (: n. m. Żukowo w pow. kartuskim Gór 253; Ry II 765; SEMot 3 232; SG XIV 848-850; SSNO VI 371). W badanym materiale onimicznym występują również nazwiska genetycznie niemieckie derywowane od nazw miejscowych przy użyciu sufiksu -er: Marianna Lenzer, rodzice Michael i Marianna, 1758, 63 (: niem. n. os. Lenzer, Lezner < n. m. Lenz, Lenze Ry II 15; SG V 144) i Jacobus Leyzer, rodzice Michael i Marianna, 1756, 57 (: niem. n. os. Leisner < niem. n. m. Leisen, Leissen Ry II 7), a także równe formalnie nazwie miejscowości: Martinus Szembek, rodzice Josephus i Marianna, 1751, 41 (: dniem. n. os. Schembeck < niem. n. m. Schönbek < śrdniem. ap. schôn(e) 'piękny' + śrdniem. ap. beke 'strumień, potok', $\ddot{o}$ uległo delabializacji w $e$, a wskutek asymilacji $n b$ przeszło w $m b$ Czopek-Kopciuch 136; Gott 151, 523; Gór 218; Lasch 132; Lbn I 09, IV 114; Lic 189; Ry II 534; Zoder II 548-549).

Powyższy opis nazwisk polega jedynie na odtworzeniu pragmatycznych aspektów nominacji i uwypukleniu znaczenia motywujących podstaw słowotwórczych. Zmierzał zatem przede wszystkim do wykrycia myślowych schematów nazwotwórczych. Taki wielopłaszczyznowy opis wybiega poza stricte językowe mechanizmy nominacyjne, ale wydaje się dzisiaj bardziej inspirujący. Nowsze metody interpretacji antroponimów korzystają bowiem zarówno z tradycyjnych sposobów

\footnotetext{
${ }^{21}$ Możliwa jest również inna motywacja: od n. os. Rogal, Rogala, Rogali Kemp 275.

${ }^{22}$ Możliwa jest również inna motywacja: od n. os. Suka < ap. suka Gór 213.
} 
analizy, jak i nowszych interdyscyplinarnych metodologii odwołujących się do wiedzy pozajęzykowej, psycholingwistyki, etnolingwistyki, socjolingwistyki, a także do coraz wyraźniejszego $\mathrm{w}$ językoznawstwie kognitywnym nurtu aksjologicznego (Bartmiński 2007; Kaleta 2003: 21-48). Niestety, analizowane rękopisy nie zawierały informacji o pozycji społecznej czy zawodzie wykonywanym przez rodziców dzieci wymienionych w dokumentach. Brak tych dodatkowych określeń identyfikacyjnych uniemożliwił zatem analizę onimów pod kątem socjolingwistycznym.

Przedmiotem niniejszej pracy było przede wszystkim ukazanie kontekstów pragmatycznych towarzyszących nominacji, uwarunkowanych ludzką percepcją, sposobami postrzegania świata i generalizowania rzeczywistości. Wśród analizowanych nazwisk najwięcej jest antroponimów motywowanych przez apelatywy (24), następnie nazwy miejscowe (17), najmniej zaś — przez imiona (12). W zbiorze onimów znalazły się zatem nazwiska, w których ukryta została symbolika zwierząt, np.: Bocian, Mucha, i roślin, np. Kakol, oraz takie, w których utrwalono charakterystyczne cechy ich nosicieli i wykonywane zajęcie, np.: Popielarz, Szulc. Ponadto wyróżniono liczne nazwiska zawierające sufiksy o charakterze deminutywno-ekspresywnym, np.: Reszka, i patronimicznym, np.: Julewicz, Zdanowicz. Wśród antroponimów motywowanych przez nazwy miejscowe wystapiły nazwiska utworzone przede wszystkim od nazw wsi znajdujących się w powiatach położonych blisko Osia: elbląskim, kartuskim, radziejowskim i sępoleńskim. Występowanie niemieckiego substratu w onimach z badanego terenu jest natomiast konsekwencją kolonizacji niemieckiej, której początki sięgają XIII w.

\section{LITERATURA}

Bartmiński J. 2007: Językowe podstawy obrazu świata, Wyd. UMCS, Lublin.

Brech I - Brechenmacher J. 1957-1963: Etymologisches Wörterbuch der deutschen Familiennamen, 2. Aufl., Bd. I, C. A. Starke Verl., Limburg a. d. Lahn.

Brech II — Brechenmacher J. 1957-1963: Etymologisches Wörterbuch der deutschen Familiennamen,

2. Aufl., Bd. II, C. A. Starke Verl., Limburg a. d. Lahn.

Czopek-Kopciuch — Czopek-Kopciuch B. 1995: Adaptacje niemieckich nazw miejscowych w języku polskim, Wyd. IJP PAN, Kraków.

Gott — Gottschald M. 1971: Deutsche Namenkunde: Unsere Familiennamen nach ihrer Entstehung und Bedeutung, de Gruyter, Berlin.

Gór — Górnowicz H. 1992: Stownik nazwisk mieszkańców Powiśla Gdańskiego, Wyd. UG, Gdańsk.

Grzybowski S. 1957: Nazwisko i jego stałość jako element identyfikacyjny osoby w dawnym prawie polskim, „Onomastica” III, s. 485-514.

Heintze - Heintze A., Cascorbi P. 2004: Die deutsche Familiennamen geschichtlich, geographisch, sprachlich, Verl., der Buchhandlung des Waisenhauses, Hildensheim-Zürich-New York.

Kaleta Z. 1991: Ewolucja nazwisk słowiańskich. Studium teoretyczno-porównawcze, IJP PAN, Kraków.

Kaleta Z. 2003: Wartości i antywartości w staropolskich odapelatywnych nazwiskach osób, [w:] E. Rzetelska-Feleszko (red.), Nazwy własne a kultura. Polska i inne kraje stowiańskie, Slawistyczny Ośrodek Wydawniczy PAN, Warszawa, s. 21-48. 
Kemp — Matusiak-Kempa I. 2009: Nazwiska mieszkańców komornictwa jeziorańskiego (XVI$-X V I I I$ w.), Wyd. UWM, Olsztyn.

$\mathrm{Kr}$ — Kreja B. 1998: Księga nazwisk ziemi gdańskiej, Wyd. UG, Gdańsk.

Lasch — Lasch A. 1914: Mittelniederdeutsche Grammatik, Verl., von Max Niemeyer, Halle.

Lbn I — Lübben A., Schiller K. 1875: Mittelniederdeutsches Wörterbuch, Bd. I, Kühtmann [u.a.], Bremen.

Lbn III — Lübben A., Schiller K. 1877: Mittelniederdeutsches Wörterbuch, Bd. II, Bd. I, Kühtmann [u.a.], Bremen.

Lbn IV — Lübben A., Schiller K. 1878: Mittelniederdeutsches Wörterbuch, Bd. IV, Bd. I, Kühtmann [u.a.], Bremen.

Lex — Lexers M. 1981: Mittelhochdeutsches Taschenwörterbuch, S. Hirzel Verl., Stuttgart.

Lic — Lica Z. 2009: Sposoby adaptacji nazwisk pomorskich genetycznie niemieckich w polszczyźnie, Wyd. UG, Gdańsk.

Naum - Naumann H. 1989: Familiennamenbuch, Bibliographisches Institut, Leipzig.

NP I — Breza E. 2000: Nazwiska Pomorzan. Pochodzenie i zmiany, t. I, Wyd. UG, Gdańsk.

NP II — Breza E. 2002: Nazwiska Pomorzan. Pochodzenie i zmiany, t. II, Wyd. UG, Gdańsk.

NP III — Breza E. 2004: Nazwiska Pomorzan. Pochodzenie i zmiany, t. III, Wyd. UG, Gdańsk.

Puzynina J. 1992: Język wartości, PWN, Warszawa.

Rosp — Rospond S. 1973: Stownik nazwisk ślaskich, cz. 2: G-K, Ossolineum, Wrocław.

Ry I — Rymut K. 1999: Nazwiska Polaków. Stownik historyczno-etymologiczny, t. I: A-K, Wyd. IJP PAN, Kraków.

Ry II — Rymut K. 2001: Nazwiska Polaków. Stownik historyczno-etymologiczny, t. II: L-Ż, DWN, Kraków.

Rymut K. 1998: Nazwisko, [w:] E. Rzetelska-Feleszko (red.), Polskie nazwy własne. Encyklopedia, Wyd. IJP PAN, Warszawa-Kraków, s. 143-160.

Rymut K. 2003: Imię - nazwisko - przezwisko w historii języka polskiego, [w:] K. Rymut, Szkice onomastyczne i historycznojęzykowe, Wyd. IJP PAN, Kraków, s. 82-86.

SEMot 1 - Cieślikowa A. i in. (oprac.) 2000: Stownik etymologiczno-motywacyjny staropolskich nazw osobowych, cz. 1: Odapelatywne nazwy osobowe, DWN, Kraków.

SEMot 3 - Kaleta Z. i in. (oprac.) 1997: Stownik etymologiczno-motywacyjny staropolskich nazw osobowych, cz. 3: Odmiejscowe nazwy osobowe, Wyd. IJP PAN, Kraków.

SEMot 5 - Klimek Z. 1997: Stownik etymologiczno-motywacyjny staropolskich nazw osobowych, cz. 5: Nazwy osobowe pochodzenia niemieckiego, DWN, Kraków.

SG - Sulimierski F. i in. (red.)1880-1902: Stownik geograficzny Królestwa Polskiego i innych krajów stowiańskich, http://dir.icm.edu.pl/Slownik_geograficzny/(dostęp 20 VI 2016).

Skowronek K. 2001: Wspótczesne nazwisko polskie. Studium statystyczno-kognitywne, DWN, Kraków.

SL VI — Linde B. 1951: Słownik języka polskiego, t. VI, PIW, Warszawa.

SSNO I — Taszycki W. (red.) 1965-1967: Stownik staropolskich nazw osobowych, t. I, Ossolineum, Wrocław.

SSNO II — Taszycki W. (red.) 1968-1970: Stownik staropolskich nazw osobowych, t. II, Ossolineum, Wrocław.

SSNO III — Taszycki W. (red.) 1971-1973: Stownik staropolskich nazw osobowych, t. III, Ossolineum, Wrocław.

SSNO IV — Taszycki W. (red.) (1974-1976): Stownik staropolskich nazw osobowych, t. IV, Ossolineum, Wrocław.

SSNO V — Taszycki W. (red.) (1977-1978): Stownik staropolskich nazw osobowych, t. V, Ossolineum, Wrocław.

Zoder I - Zoder R. 1968: Familiennamen in Ostfalen, Bd. I, Georg Olms Verlagsbuchhandlung, Hildesheim. 
Zoder II - Zoder R. 1968: Familiennamen in Ostfalen, Bd. II, Georg Olms Verlagsbuchhandlung, Hildesheim.

http://doroszewski.pwn.pl/haslo/mucha (dostęp 15 IX 2016).

http://www.osie.pl/historia/historia.html (dostęp 28 VIII 2015)

\section{SKRÓTY}

$$
\begin{aligned}
& \text { akad. — akadyjski } \\
& \text { ap. - apelatyw } \\
& \text { aram - aramejski } \\
& \text { bibl. - biblijne } \\
& \text { dniem. - dolnoniemiecki } \\
& \text { gniem. - górnoniemiecki } \\
& \text { gw. - gwarowy } \\
& \text { hebr. - hebrajski } \\
& \text { im. - imię } \\
& \text { łac. - łaciński } \\
& \text { n. - nazwa }
\end{aligned}
$$

$$
\begin{array}{ll}
\text { n. m. } & \text { - nazwa miejscowa } \\
\text { n. os. } & \text { - nazwa osobowa } \\
\text { niem. } & \text { - niemiecki } \\
\text { por. } & \text { - porównaj } \\
\text { pow. } & \text { - powiat } \\
\text { stp. } & \text { - staropolski } \\
\text { śrdniem. } & \text { - średnio-dolno-niemiecki } \\
\text { śrniem. } & \text { - środkowoniemiecki } \\
\text { śrwniem. } & \text { - średnio-wysoko-niemiecki } \\
\text { ts. } & \text { - to samo }
\end{array}
$$

\section{SELECTED POLISH SURNAMES FROM OSIE PARISH FROM THE BOOK OF BAPTISMS (1751-1760)}

\section{SUMMARY}

The article presents the analysis of the surnames derived of families living in the parish of Osie (kujawsko-pomorskie province). The anthroponyms (53 in total) have been extracted from the church registers pertaining to baptisms from the second part of the $18^{\text {th }}$ century.

The surnames have been divided into three groups - motivated by appellative vocabulary, given names and village names. The article presents this linguistic phenomenon of creating names.

Keyw ord s: onomastics, anthroponymy, Polish surnames 